\title{
A significant 'coronary steal' by thebesian veins, a rare congenital coronary defect masquerading as acute coronary syndrome
}

\author{
Rajib Alam, John Skehan, Ashan Gunarathne
}

Department of Cardiology, Glenfield Hospital, Leicester, UK

\section{Correspondence to}

Dr Rajib Alam, rajibalam17@yahoo.co.uk

Accepted 1 March 2015
CrossMark

\begin{tabular}{l}
\hline To cite: Alam R, Skehan J, \\
Gunarathne A. BMJ Case \\
Rep Published online: \\
[please include Day Month \\
Year] doi:10.1136/bcr-2014- \\
208880
\end{tabular}

\section{DESCRIPTION}

A 72-years-old woman presented with intermittent chest pains, anterolateral $\mathrm{T}$-wave inversions on ECG and troponin-T of $6290 \mathrm{ng} / \mathrm{L}$. Acute coronary syndrome treatment was initiated. The coronary angiography demonstrated tortuous calcified coronaries without any significant obstructive lesion. However, late dye acquisition images revealed a capillary blush originating from the diagonal branch of left anterior descending artery (figures 1 and 2) and the distal right coronary artery (figures 3 and 4 ) feeding into the ventricular cavity through intramural thebesian vein connections, almost producing a ventriculogram (figures 5 and 6).

This episode which otherwise would been an undetectable plaque event, turned out to be one of significant myocardial injury due to background presence of the 'the coronary steal' syndrome.

Persistence of embryonic coronary artery fistulas in form of diffuse vascular network directly draining oxygenated blood from the coronaries into the ventricles bypassing the myocardial capillary network are called thebesian veins. Coronary artery fistulas are rare $\left(<0.2 \%{ }^{1}\right)$, remain silent and often discovered incidentally on coronary angiogram or

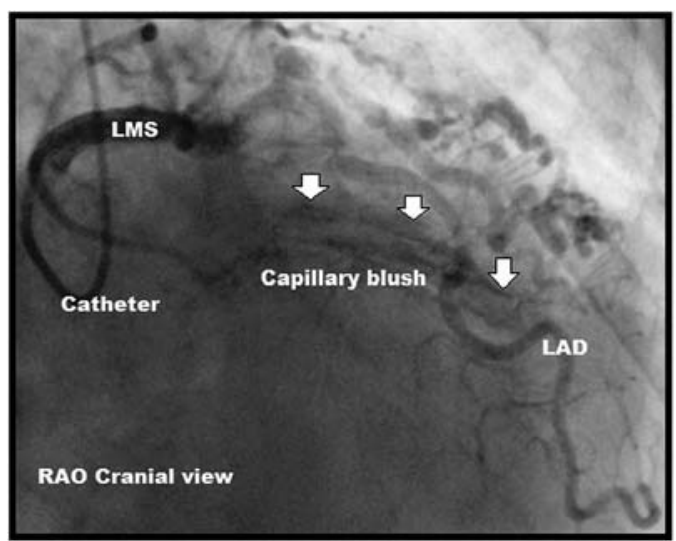

Figure 1 The flow through the coronary artery fistula (thebesian veins) in the diagonal branch of left anterior descending artery is seen (in late dye acquisition images) as a capillary blush (marked with arrows) in the RAO cranial view. This flow is causing drainage of oxygenated blood directly from coronaries into the ventricular cavity.

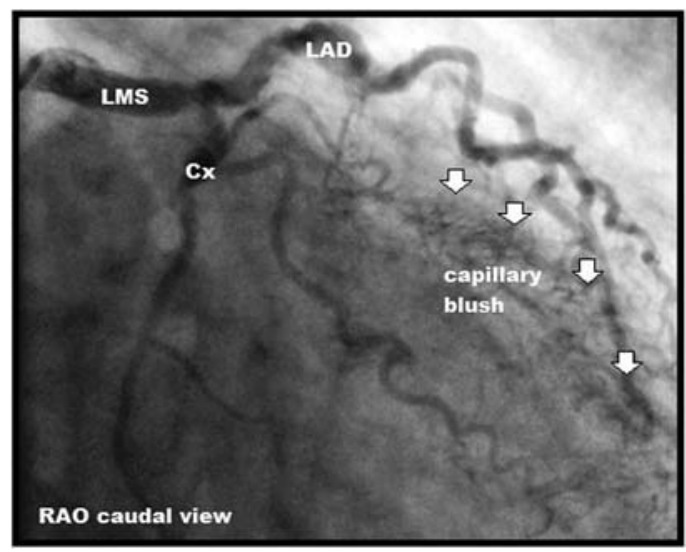

Figure 2 The flow through the coronary artery fistula (thebesian veins) in the diagonal branch of left anterior descending artery is seen (in late dye acquisition images) as a capillary blush (marked with arrows) in the RAO caudal view. This flow is causing drainage of oxygenated blood directly from coronaries into the ventricular cavity.

ventriculography. ${ }^{2}$ They rarely become haemodynamically significant and become a nonatherosclerotic cause of angina via the coronary steal phenomenon. $^{3}$ Case reports of steal

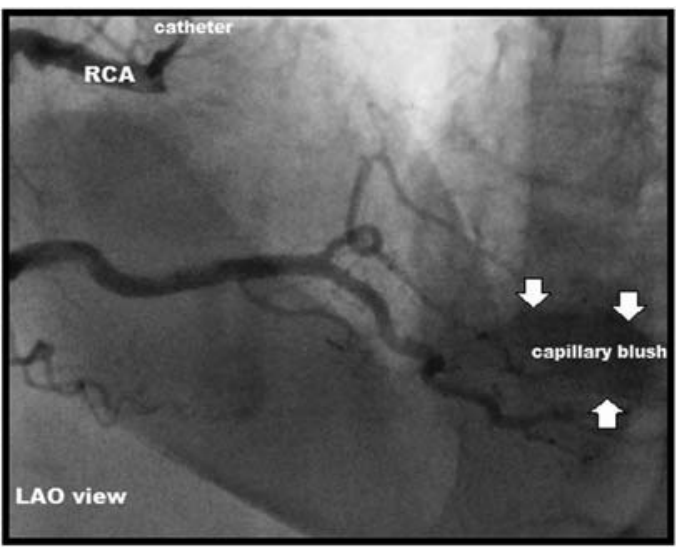

Figure 3 The flow through the coronary artery fistula (thebesian veins) in the distal right coronary artery is seen (in late dye acquisition images) as a capillary blush (marked with arrows) in the LAO view. This flow is causing drainage of oxygenated blood directly from coronaries into the ventricular cavity. 


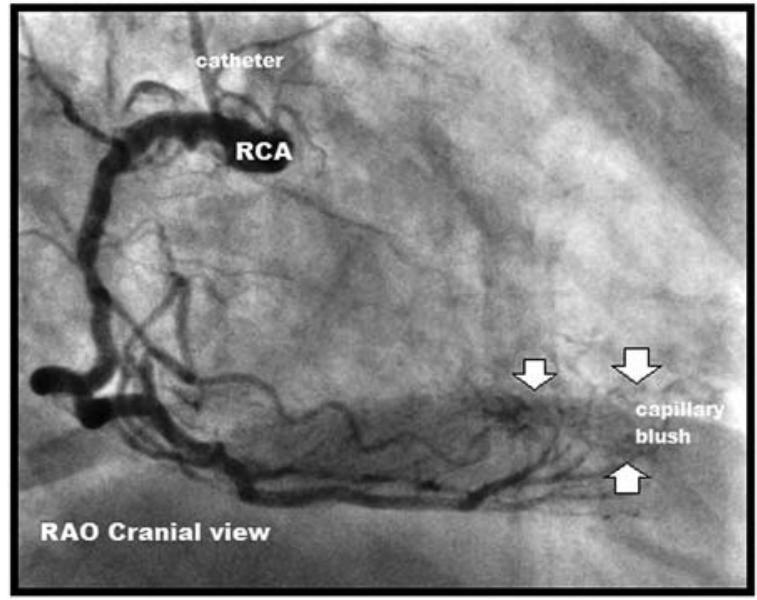

Figure 4 The flow through the coronary artery fistula (thebesian veins) in the distal right coronary artery is seen (in late dye acquisition images) as a capillary blush (marked with arrows) in the RAO cranial view. This flow is causing drainage of oxygenated blood directly from coronaries into the ventricular cavity.

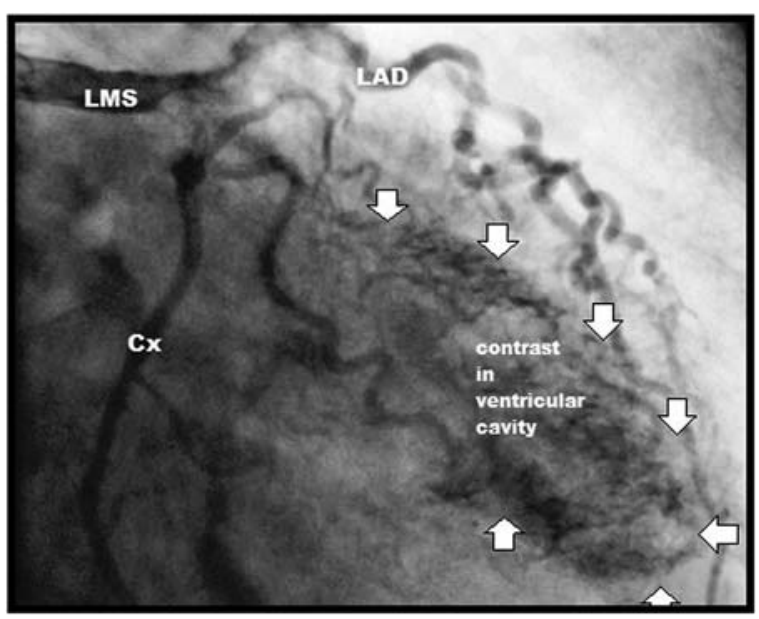

Figure 5 The flow of contrast through the thebesian veins into the ventricular cavity producing a ventriculogram (ventricle seen in systole).

\section{Learning points}

- Non-atherosclerotic coronary arterial anomaly may be associated with myocardial ischaemia producing angina symptoms and troponin rise.

- A good image for cardiology trainees to remember.

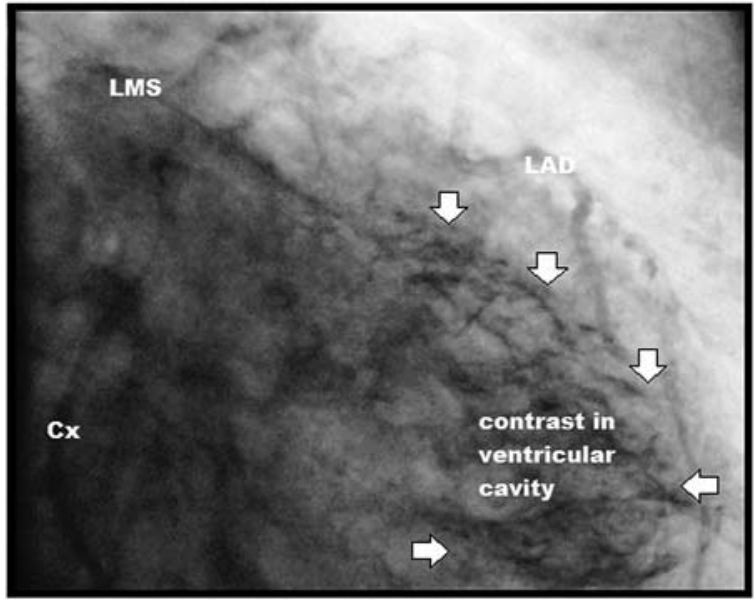

Figure 6 The flow of contrast through the thebesian veins into the ventricular cavity producing a ventriculogram (ventricle seen in diastole).

phenomenon are reported in adults ${ }^{4}$ and neonates. ${ }^{6}$ A case of paradoxical exacerbation of myocardial ischaemia with nitrates increasing the 'steal' is reported. ${ }^{7}$ People may present with ischaemic ECG changes, ${ }^{48}$ positive troponin ${ }^{4}$ and even bacterial endocarditis. 9 These malformations were also reported in a carrier of fragile X syndrome. ${ }^{10}$

Contributors RA prepared the manuscript while AG supervised the manuscript. JS is the consultant responsible for the patient.

\section{Competing interests None.}

Patient consent Obtained.

Provenance and peer review Not commissioned; externally peer reviewed.

\section{REFERENCES}

1 Stierle U, Giannitsis E, Sheikhzadeh A, et al. Myocardial ischemia in generalized coronary artery-left ventricular microfistulae. Int J Cardiol 1998;63:47-52.

2 Judkins C, Yamen E. Inadvertent thebesian vein cannulation during radial access ventriculography. JACC Cardiovasc Interv 2013;6:e9-10.

3 Levin DC, Fellows KE, Abrams HL. Hemodynamically significant primary anomalies of the coronary arteries. Angiographic aspects. Circulation 1978;58:25-34.

4 Chattopadhyay S, Wahab N, O'Reilly K. Persistent thebesian veins presenting with myocardial ischemia. Can J Cardiol 2010;26:e31-2.

5 Krishnan U, Schmitt M. Images in cardiovascular medicine. Persistent thebesian sinusoids presenting as ischemic heart disease. Circulation 2008;117:e315-16.

6 Skimming JW, Walls JT. Congenital coronary artery fistula suggesting a "steal phenomenon" in a neonate. Pediatr Cardiol 1993;14:174-5.

7 Heper $G$, Kose $S$. Increased myocardial ischemia during nitrate therapy caused by multiple coronary artery-left ventricle fistulae? Tex Heart Inst J 2005;32:50-2.

8 Jung $\mathrm{Y}$, Kim $\mathrm{H}$, Yoon $\mathrm{CH}$. Severe form of persistent thebesian veins presenting as ischemic heart disease. Korean Circ J 2012;42:714-17.

9 Alkhulaifi AM, Horner SM, Pugsley WB, et al. Coronary artery fistulas presenting with bacterial endocarditis. Ann Thorac Surg 1995;60:202-4.

10 Koganti S, Gunarathne A, Desai P, et al. A rare type of 'coronary arterial - left ventricular fistula' via thebesian veins in a Fragile $\mathrm{X}$ syndrome carrier. Cardiol J 2011;18:318-19. 
Copyright 2015 BMJ Publishing Group. All rights reserved. For permission to reuse any of this content visit http://group.bmj.com/group/rights-licensing/permissions.

BMJ Case Report Fellows may re-use this article for personal use and teaching without any further permission.

Become a Fellow of BMJ Case Reports today and you can:

- Submit as many cases as you like

- Enjoy fast sympathetic peer review and rapid publication of accepted articles

- Access all the published articles

- Re-use any of the published material for personal use and teaching without further permission

For information on Institutional Fellowships contact consortiasales@bmjgroup.com

Visit casereports.bmj.com for more articles like this and to become a Fellow 